\title{
ע SOUND CHANGES IN THE (PRE-)MASORETIC READING TRADITION AND THE ORIGINAL PRONUNCIATION OF BIBLICAL ARAMAIC
}

\author{
Benjamin D. Suchard \\ Leiden University
}

\begin{abstract}
For nearly a thousand years, the texts of the Hebrew Bible were transmitted both in writing, as consonantal texts lacking much of the information about their pronunciation, and orally, as an accompanying reading tradition which supplied this information. During this period of oral transmission, sound changes affected the reading tradition. This paper identifies a number of sound changes that took place in the reading tradition by comparing their effects on Biblical Hebrew to those on Biblical Aramaic, the related but distinct language of a small part of the biblical corpus. Sound changes that affect both languages equally probably took place in the reading tradition, while those that are limited to one language probably preceded this shared oral transmission. Drawing this distinction allows us to reconstruct the pronunciation of Biblical Aramaic as it was fixed in the reading tradition, highlighting several morphological discrepancies between the dialect underlying it and that of the consonantal texts.
\end{abstract}

\section{INTRODUCTION}

The Biblical Aramaic corpus as it has reached us, like the rest of the Hebrew Bible, is a hybrid. ${ }^{1}$ The texts were originally composed in the second half of the first millennium BCE (Gzella 2011:583). Due to the largely consonantal nature of the script, however, much of the phonetic information needed to actually pronounce even a single word was missing from these texts. Readers either had to supply this missing information based on their knowledge of the language - as modernday readers of (unvocalized) Hebrew or Arabic do without too much trouble - or had to rely on an orally transmitted reading tradition, which allowed them to memorize the pronunciation of each verse and in that way compensate for the orthography's deficiencies. Only from the sixth century CE onwards, and culminating in the tenth century, were orthographic means devised to

\footnotetext{
1 This paper was written as a part of the project "The origins of the Biblical Aramaic reading tradition", generously supported by Stichting Studiecentrum voor Judaïca en Hebraïca Dr L. Fuks. I am grateful to Marijn van Putten for his insightful comments on an earlier draft, to the two anonymous reviewers of this paper, and to the audience of a talk I gave on this topic at the session of the Groupe Linguistique d'Études Chamito-Sémitiques (Paris, 21 Nov. 2018) for their thoughts. All remaining errors are my own. I also thank Krzysztof Baranowski for pointing me towards the highly relevant article by Fox (2017).
}

Volume 7 (2019), pp. 52-65

DOI $10.23993 /$ store. 74104

Licensed under Creative Commons Attribution 3.0 License.

ISSN: 2323-5209

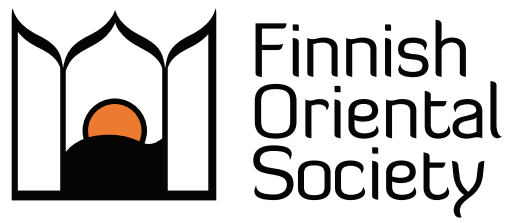


mark ever more detailed features of the pronunciation as it was known to the Masoretes, the expert readers responsible for this vocalization (Khan 2013a: 1-4).

Even after most of the features of the reading tradition became fixed in writing, the pronunciation of the text continued to evolve. One may compare the many different variations found, for instance, in the Ashkenazi pronunciations of Eastern and Central Europe, where, for example, the vowel indicated by holem was pronounced either as [o:] or [ou] (Southern Germany), [au] (the Netherlands and Northern Germany), [oi] (Poland, Galicia, Central Europe), or [ei] (Lithuania). ${ }^{2}$ It stands to reason, then, that the pronunciation of the biblical texts must also have undergone many changes during the period before the vocalization was introduced, and perhaps all the more so (see Sáenz-Badillos 1993: 78). This is confirmed by Greek and Latin transcriptions predating the invention of the vocalization (see Suchard forthcoming).

An interesting feature of Biblical Aramaic is that it is vocalized using the same system as Biblical Hebrew, even though it is a different language. Apparently, the Masoretes pronounced Biblical Aramaic with the same surface-level vowels and consonants as Biblical Hebrew (although these sometimes occur in positions where they cannot in the latter language). In fact, depending on the analysis applied to Tiberian Biblical Hebrew, Tiberian Biblical Aramaic can even be described as having the same phonology (see $\S 2.1$ below). This may be explained by the long period of time in which the Biblical Aramaic texts were passed on as part of the greater biblical corpus, of which roughly 99 percent is Hebrew. Even if the earliest readers, fluent in both Hebrew and Aramaic, made an effort to pronounce the Aramaic passages differently from the majority of Hebrew passages, it is easy to imagine how later on, one and the same system of pronunciation came to be applied to the entire Hebrew Bible (see Bauer \& Leander 1927: § 2c), much like, for instance, Western school pronunciations of Greek are often strongly influenced by the pronunciation of Latin, which itself tends to be heavily influenced by the local vernacular (see Allen 1987:140-161). Accordingly, sound changes that affected one of the biblical languages in this period should also be visible in the other, as they took place in the shared, Biblical Hebrew-Aramaic reading tradition.

We must note that for the latest period, it is inaccurate to speak of one biblical reading tradition: the differences between the Tiberian, Palestinian, and Babylonian vocalization systems of the Hebrew Bible are not just orthographic, but also reflect different traditional pronunciations of the texts (Sáenz-Badillos 1993: 86-111). Yet another tradition is reflected in the earlier Greek transcriptions found in the Second Column of the Hexapla, dating to the third century CE at least (see Brønno 1943; Janssens 1982; Kantor 2017). The linguistic differences between these reading traditions are small enough, however, that they can be derived from a common ancestor without too much trouble. These reading traditions are all associated with Rabbinic Judaism and show a much closer resemblance to each other than any of them do to the Hebrew reflected in non-Jewish or pre-Rabbinic sources (like the Samaritan Pentateuch or the Hebrew transcriptions found in the Septuagint). The term "the reading tradition" as used in this article, then, refers to the period of transmission from the codification of this unified Rabbinic Jewish pronunciation, probably to be dated around the beginning of the Common Era, up to the attestation of the various pronunciations in writing. As the complete vocalized text of the Hebrew

\footnotetext{
2 See Glinert 2013. While these pronunciations do not directly derive from the Tiberian pronunciation as reflected in the Tiberian Masoretic Text, the point remains that even after an authoritative vocalization of the text was accepted, the phonetics of the pronunciation could still change (assuming this variation only originated after the adoption of the Tiberian vocalization by Ashkenazic Jewry in the 14th century; see Eldar 2013).
} 
Bible has only reached us in its Tiberian Masoretic form, this is the version of the text this paper will take as its point of departure. ${ }^{3}$

By comparing the presence or absence of individual sound changes in Tiberian Biblical Hebrew and Tiberian Biblical Aramaic, we have a way of establishing whether they took place in the reading tradition, that is, during the period of time in which the pronunciation of the biblical corpus as a whole was transmitted orally. If a sound change operates the same way in Biblical Hebrew and in Biblical Aramaic, it probably took place in the shared reading tradition. If it is limited to one of these languages only, however, it probably took place at an earlier time, either in the living languages or, if reading traditions for separate parts of the biblical corpus already existed before a unified reading tradition came into being, in these separate traditions. This gives us a falsifiable prediction: if the scenario of the transmission of the biblical texts sketched above is correct, sound changes that occur in both languages should postdate those that are limited to one language when incorporated into a relative chronology. It also gives us a way to more accurately reconstruct the forms of Hebrew and Aramaic that formed the basis of the reading tradition. If we subtract all the sound changes that affected both parts of the corpus during their shared transmission, what is left should be very close to the pronunciation of Biblical Hebrew and Biblical Aramaic that was used before the first sound changes took place in the reading tradition, that is, the form in which the reading tradition was codified. ${ }^{4}$

We will examine a number of sound changes that can aid in this endeavour. Section 2 discusses sound changes that appear to have affected Biblical Hebrew and Biblical Aramaic equally (excluding the extremely early changes that should be traced back to Proto-NorthwestSemitic, for obvious reasons). In Section 3, we will see a number of sound changes that we might expect to have affected both languages, but which are instead limited to just one of them. Section 4 summarizes these results, concluding that the relative chronology of the sound changes is compatible with the late date of those assigned to the reading tradition, and illustrates the reconstruction of the earliest pronunciation of Biblical Aramaic. Intriguingly, this pronunciation is incompatible with the consonantal orthography of the texts, raising questions about how the reading tradition came to be fixed in the first place.

\footnotetext{
3 Considering the Babylonian tradition, Morag (1964:120) notes that "the Bab. Mss. show a number of nonTiberian peculiarities that are common to the Bab. traditions of both Hebrew and Aramaic", listing ten features. These features all reflect Babylonian sound changes or the absence of Tiberian sound changes that can be shown to postdate the stage of the reading tradition reconstructed in this article, which is consistent with the scenario where these sound changes took place during the transmission of the reading tradition. Two features that Morag notes as affecting Babylonian Biblical Aramaic but not Babylonian Biblical Hebrew are the outcome of the short stressed $*_{i}$ (consistently $e$ in Babylonian Biblical Aramaic) and the contraction of the word-internal diphthong *ay in some manuscripts. These are both sounds that show differential treatment in Tiberian Biblical Aramaic and Tiberian Biblical Hebrew, too (see $\S 3.1-3.2$ ), supporting the suggestion that they underwent different sound changes in Hebrew and Aramaic before the creation of a unified biblical reading tradition. Thus, the Babylonian evidence is consistent with the conclusions drawn from the Tiberian evidence in the main text of this paper.

4 Alternatively, changes that operate the same way in both languages may reflect phonological rules that were synchronically active in one of the two languages at the time the reading tradition was fixed. Afterwards, these could have been applied to the other language. Thus, if the spirantization of non-emphatic plosives (bgdkpt) was a synchronic rule of the dialect underlying Biblical Aramaic, it could simply have been applied to the reading tradition of the Hebrew part of the corpus, even if the diachronic change that caused the spirantization was much older. In this case, reverting the texts to a pre-spirantization form would not bring us closer to the phonetic reality of the first readers, although it would reveal the underlying phonemes as being plosives at that point in time: if spirantization was synchronically active, then it was not yet phonemic, by definition.
} 


\section{SHARED DEVELOPMENTS BETWEEN BIBLICAL HEBREW AND BIBLICAL ARAMAIC}

\subsection{Phonetic changes}

Opinions are divided on how the synchronic phonology of Tiberian Biblical Hebrew should be analysed. Following analyses that stick close to the surface forms, like those by Geoffrey Khan (2013b; 2013c) and myself (Suchard 2018), Tiberian Biblical Hebrew and Tiberian Biblical Aramaic have the same phonology: they share the same phonemes, and the same phonological rules convert underlying representations to surface forms. Note that the effects of these rules are not marked in the vocalization (or otherwise in the Masoretic Text), but are known to us from contemporary and nearly contemporary grammatical descriptions and transcriptions in Arabic script. In this analysis, then, the Tiberian vocalization only marks phonemic contrasts, which sits well with the fact that speakers are typically unaware of the allophony they produce and the phonological rules they employ. Since phonological rules largely originate as sound changes, it is no surprise that the late sound changes that yielded these rules can also be posited for both Biblical Hebrew and Biblical Aramaic. These include (see Khan 1996; 2013a: 85-107; examples are given below): ${ }^{5}$

a) the lengthening of every accented vowel;

b) the change of $* w$ to $[\mathrm{v}]$ when not adjacent to an $u$ vowel;

c) the partial shortening of long vowels in open syllables immediately preceding the stress;

d) the change of $* r$ to $\left[\mathrm{r}^{\mathrm{s}}\right]$ when adjacent to or in the same underlying syllable as a preceding coronal (excluding $\check{s}$ ) or following $l$ or $n$, and to [R] elsewhere;

e) and the assimilation of * $\partial$ to the quality of the next vowel when a guttural intervenes, assimilation to $i$ before $y$, and change to [a] elsewhere.

Examples:

\begin{tabular}{|c|c|c|c|c|}
\hline form & pronunciation & earlier form & meaning & language \\
\hline \multicolumn{5}{|c|}{ a. lengthening of accented vowels } \\
\hline עַד & ['ৎa:ð] & $<*$ Cád $^{\prime}$ & 'until' & both \\
\hline 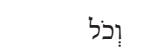 & [va' $\chi 0: 1]$ & $<* v a k o ́ l$ & 'and all (construct)' & both \\
\hline 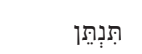 & [thin' the:n] & $<*$ tintén & 'you (m.sg.) will give' & Aramaic \\
\hline 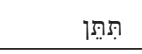 & {$\left[\mathrm{t}^{\mathrm{h}} \mathrm{it}^{\prime} \mathrm{t}^{\mathrm{h}} \mathrm{e}: \mathrm{n}\right]$} & $<*$ tittén & 'you (m.sg.) will give' & Hebrew \\
\hline \multicolumn{5}{|c|}{ b. ${ }^{*} w>[v]$ when not adjacent to $[u]$} \\
\hline וְאָמַר & [vo?s'ma:R] & 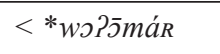 & 'and says (m.sg.)' & Aramaic \\
\hline וִאָמַר & [vors' 'ma:R] & $<*$ *wว?̄már & 'and he will say' & Hebrew \\
\hline הָוָא & [ha'vo:] & $<* h a w \hat{\jmath}$ & 'he was' & Aramaic \\
\hline וְאַנְוְהוּוּ & [va?an've:hu:] & $<*$ waranwéh $\bar{u}$ & 'and I will praise him' & Hebrew \\
\hline נְחוּוּא & [nahav've:] & $<*$ nahawwé & 'we will tell' & Aramaic \\
\hline 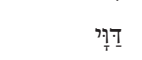 & [dav'vo:j] & $<* d a w w \bar{\partial} y$ & 'faint' & Hebrew \\
\hline וְהוּא & [wu'hu:] & $<* w u h \dot{u}$ & 'and he' & both \\
\hline לִפְּוָה & [lafuw'wo:] & $<* l a \bar{p} u w w \bar{\jmath}$ & 'to Pua' & Hebrew \\
\hline
\end{tabular}

5 Phonetic surface forms in the Tiberian pronunciation are given in the International Phonetic Alphabet and surrounded by [square brackets]. For some divergences from the transcription used by Khan, see Suchard 2018. Reconstructed forms are given in a more traditional Semitist transcription. 


\begin{tabular}{|c|c|c|c|c|}
\hline form & pronunciation & earlier form & meaning & language \\
\hline \multicolumn{5}{|c|}{ c. pretonic shortening of long vowels } \\
\hline !וֹאָמר & [vo?o'ma:r] & $<*$ *wP̄̄már & 'and says (m.sg.)' & Aramaic \\
\hline !ְָָמַר & [vo?s' 'ma:R] & $<* w \supset$ & 'and he will say' & Hebrew \\
\hline דִִִּילָה & [dihi' 'lo:] & $<* \operatorname{diḥīló~}$ & 'frightening (f.sg.)' & Aramaic \\
\hline 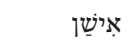 & [?i' 'a:n] & $<*$ Pǐśán & 'I will sleep' & Hebrew \\
\hline לְהוֹדָעוּתָּך & 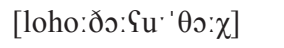 & $<* l o h \bar{o} \underline{d} \bar{s} \varphi \bar{u} \underline{t} \bar{s} \underline{k}$ & 'in order to let you know' & Aramaic \\
\hline הוּקַם & [hu' 'qa:m] & $<* h \bar{u} q a ́ m$ & 'it was erected' & Hebrew \\
\hline \multicolumn{5}{|c|}{ d. backing of $* r$} \\
\hline נְבְכדַנְנֶּר & 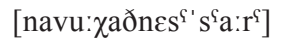 & $<* n a \underline{b} \bar{u} \underline{k} a \underline{d} n \varepsilon s \underline{s} a ́ r$ & 'Nebuchadnezzar' & both \\
\hline 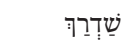 & {$\left[\int \mathrm{ad}^{\prime} \mathrm{r}^{\Upsilon} \mathrm{a}: \chi\right]$} & $<* s ̌ a d r a ́ k \underline{k}$ & 'Shadrach' & both \\
\hline (ְָ דֶרִירין) & 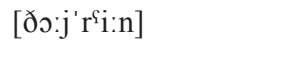 & $<*$ dȳyrîn & 'dwell (m.pl.)' & Aramaic \\
\hline גרֶרן & ['go:ricn] & $<*$ góren & 'threshing floor' & Hebrew \\
\hline יוּרוּשֶלֶם & [jaRu:f'le:m] & $<*$ yarūšlćm & 'Jerusalem' & Aramaic \\
\hline ירוּשָׁלִַם & [jaru: $\int \mathrm{o}^{\prime}$ 'la:jim] & <*yarūššláyim & 'Jerusalem' & Hebrew \\
\hline \multicolumn{5}{|c|}{ e. schwa colouring } \\
\hline וְהוּא & [wu'hu:] & $<* w a h \bar{u}$ & 'and he' & both \\
\hline וְאָמרר & [vors' 'ma:R] & $<*$ *əวิ̄̄már & 'and says (m.sg.)' & Aramaic \\
\hline !ִאָמַר & [vors' 'ma:R] & 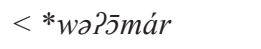 & 'and he will say' & Hebrew \\
\hline 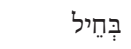 & [be'ћe:l] & <*baḥél & 'with the army (construct)' & Aramaic \\
\hline 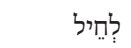 & [le'he:l] & < *lạ̣él & 'to the army (construct)' & Hebrew \\
\hline בְּיָד & [bi'ja:ð] & $<* b \partial y a ́ d$ & 'in the hand (construct)' & both \\
\hline קִרָב & [qa'ro:v] & $<* q \partial r \grave{s} \underline{b}$ & 'battle' & both \\
\hline 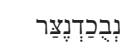 & 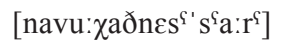 & $<* n a \underline{b} u \underline{k} a \underline{d} n \varepsilon s \underline{s} a ́ r$ & 'Nebuchadnezzar' & both \\
\hline 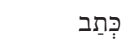 & {$\left[\mathrm{k}^{\mathrm{h}} \mathrm{a}^{\prime} \theta \mathrm{a}: \mathrm{v}\right]$} & $<* k a \underline{t a ́} \underline{b}$ & 'he wrote' & Aramaic \\
\hline כְּתב & {$\left[\mathrm{k}^{\mathrm{h}} \mathrm{a}^{\prime} \theta \mathrm{o}: \mathrm{v}\right]$} & $<* k a \underline{t} o ́ b$ & 'write (m.sg.)' & Hebrew \\
\hline
\end{tabular}

\subsection{Rounding and raising of $* \bar{a}$}

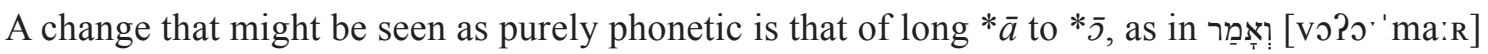
<*warāmár 'and says (m.sg.)' (Aramaic)/'and he will say' (Hebrew), קָ ['qo:mu:] < *qáamu 'they (Aramaic: m.) stood up'. Since this change was unconditioned and thus affected all instances of $* \bar{a}$, I prefer to identify the resulting phoneme as $/ \bar{\jmath} /$, in which case we should say that the change had effects at the phonemic level.

\subsection{Segolization}

The outcome of word-final consonant clusters in Biblical Aramaic, including those in the so-called segolate noun patterns ( ${ }^{*} q a t \underline{t} l,{ }^{*} q i t l l-,{ }^{*} q u t \underline{\text { t }}$ ), is problematic. As in Hebrew, an epenthetic vowel is normally inserted. However, the position of the stress is unpredictable. We find both forms with penultimate stress, resembling those found in Hebrew, and forms with ultimate stress and reduction of the historically stressed vowel, the normal pattern in other (especially non-Jewish) dialects of Aramaic. Thus, forms like *málk > מֶּלֶּ 'king' (henceforth 'Hebrew'

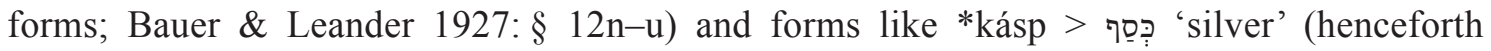
'Aramaic' forms; Bauer \& Leander 1927: § 12w-d') occur side by side. The same dichotomy 
occurs in other Jewish Aramaic dialects, such as that of Targum Onqelos. The outcome with the stress on the epenthetic vowel is regular in other dialects, like Syriac (e.g. *málk > mlek 'king', *gúšm > gšum 'body'; Brockelmann 1968: § 67).

No phonetic conditioning completely predicts the outcome of these clusters in Biblical Aramaic. More general approaches like considering the nature of the final or penultimate consonant, such as whether it is a plosive or a resonant, do not result in any significant findings either. Nor is there a significant correlation (statistically speaking) between 'Hebrew' segolization in Biblical Aramaic and Targum Onqelos: while some forms are shared by both dialects, enough forms show different reflexes that the correspondences may be due to coincidence. These facts indicate that some process other than sound change is at play. Muraoka (1976) suggests that the 'Aramaic' forms are genuine, while the 'Hebrew' forms were borrowed from the Biblical Hebrew part of the corpus. This would explain why the 'Hebrew' forms are limited to Jewish dialects of Aramaic. A problem for this account is the occurrence of 'Hebrew' forms which do not actually exist in Hebrew, such as חָלֶם 'dream' (contrast with Biblical Hebrew'). But it seems possible that the original shape of these nouns was either analogically restored (yielding *helm, which later developed to nִ during the 'Hebrew' segolization discussed below), perhaps based on suffixed and emphatic forms like חֶלְ 'the dream', or influenced by the common Hebrew segolate noun patterns, even though no exact parallel occurred in Hebrew. The 'Aramaic' segolization would then have antedated the reading tradition, while some forms restored the word-final cluster and would later go on to participate in the 'Hebrew' segolization; these are then two separate developments, with 'Hebrew' segolization only occurring centuries after 'Aramaic' segolization.

The details of the development of 'Hebrew' segolates in Biblical Aramaic are identical to the actual Hebrew forms (Bauer \& Leander 1927: $\S 12 n-u$ ): the epenthetic vowel is $a$ after gutturals

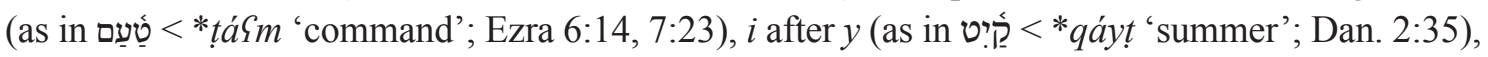

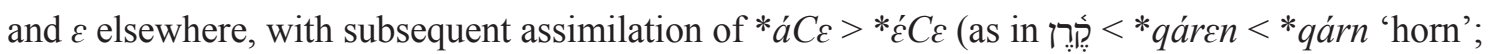
Dan. 7:8). This shows that Biblical Aramaic forms that had preserved or restored their word-final consonant cluster participated in the same set of epenthetic changes as Biblical Hebrew. The late date of this 'Hebrew' segolization is confirmed by its absence in the third-century CE Hebrew text in Greek transcription found in the Second Column of the Hexapla (Brønno 1943). ${ }^{6}$

\subsection{The vowelling of proclitic particles}

Like Biblical Hebrew, Biblical Aramaic has a number of proclitic particles: prepositions and other function words consisting of only one consonant which form an orthographic and phono-

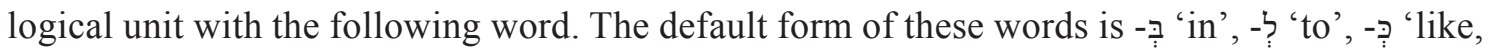
as', and -? 'and'. The vowel of these particles varies depending on the shape of their host. This variation follows a set of rules that are identical in Biblical Hebrew and Biblical Aramaic (Bauer \& Leander 1927: §69b-g, 1-q, 70b-j; once again, examples follow):

\footnotetext{
6 Hebrew names transcribed in the Septuagint do already show the presence of an epenthetic vowel in segolates

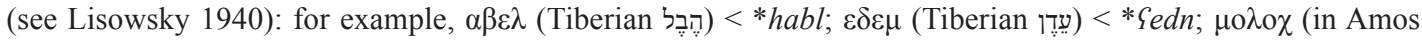
5:26, where the Masoretic Text reads differently; but cf. Tiberian מלֶֶ in Lev. 18:21)<*molk. But the transcriptions of many names show remarkable differences compared to their Tiberian forms (Staples 1927: 8). As the tradition familiar to the translators of the Septuagint is thus not a direct precursor of the reading tradition known to the Masoretes, it is unproblematic if it underwent segolization at an earlier point in time.
} 
a) If the following word starts with a consonant cluster (i.e. the first consonant carries

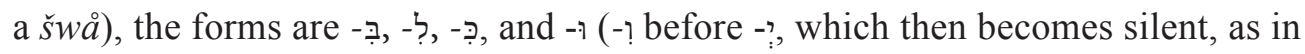

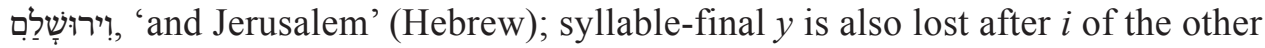
proclitics).

b) If the following consonant carries a håtep (i.e. reduced, phonemically short) vowel, the proclitic prepositions and the conjunction 'and' have a full vowel with the same quality. In Biblical Hebrew, this is only attested before gutturals, since håte $\bar{p}$ vowels only very rarely occur after other consonants. In Biblical Aramaic, these reduced vowels are more common, and the frequent Biblical Aramaic form לָז 'before' strongly suggests that the nature of the consonant was irrelevant, and it is the presence of the hattep vowel that conditions the full vowel in the proclitic. In both languages, we find before a sibilant

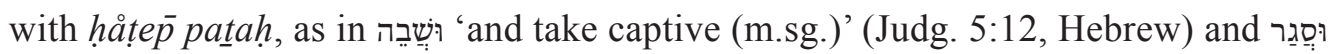
'and he locked' (Dan. 6:23, Aramaic).

c) 'And' before bilabial consonants is - - .

Examples:

\begin{tabular}{|c|c|c|c|}
\hline form without proclitic & form with proclitic & meaning & language \\
\hline \multicolumn{4}{|c|}{ a. proclitics before consonant clusters } \\
\hline שָָׁאר & בְְִּשָאָר & '(with) the rest (construct)' & Aramaic \\
\hline 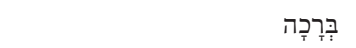 & לברברכָה & '(to) a blessing' & Hebrew \\
\hline שָָָׁר & וּשְָׁאר & '(and) the rest (construct)' & Aramaic \\
\hline 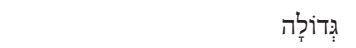 & 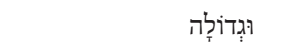 & '(and) great (f.sg.)' & Hebrew \\
\hline יוּרוּשְלֶם & בדּירוּשְלֶם & '(in) Jerusalem' & Aramaic \\
\hline ירוּשָׁלַם & 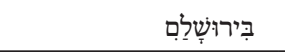 & '(in) Jerusalem' & Hebrew \\
\hline \multicolumn{4}{|c|}{ b. corresponding full vowel before håtep̄ vowels } \\
\hline אָנזָה & וַאנָנה & '(and) I' & Aramaic \\
\hline אָנִי & וַאְנִי & '(and) I' & Hebrew \\
\hline אֶלָהיה & לֶאלֶָה & '(to) the god (construct)' & Aramaic \\
\hline 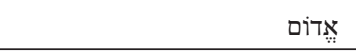 & 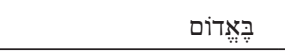 & '(in) Edom' & Hebrew \\
\hline \multicolumn{4}{|c|}{ c. $u$-before bilabial consonants } \\
\hline בֶּית & וּבֶית & '(and) the house (construct)' & both \\
\hline 鸟 & 象 7 & '(and) a mouth' & Aramaic \\
\hline הֶֶ & וּנֶּה & '(and) a mouth' & Hebrew \\
\hline
\end{tabular}

Thus, we see a shared and often arbitrary conditioning of these rules in both Tiberian Biblical Hebrew and Tiberian Biblical Aramaic - arbitrary, because other, phonetically equally understandable systems for the realization of these proclitics occur elsewhere, such as in the Babylonian tradition of Biblical Hebrew and Aramaic (where $w$-before consonant clusters yields wi-; Morag 1964:120) or in Syriac (where the epenthetic vowel is consistently $a$; Brockelmann 1968: § 165-166). This makes it quite likely that the Tiberian rules, which apply to both languages, result from the same set of developments rather than parallel development.

7 The Leningrad Codex exceptionally has וְפ in Dan. 7:20; according to the apparatus of Biblia Hebraica Stuttgartensia, many manuscripts read the normal ופְ here. 


\section{5 bgdkpt spirantization}

After vowels, including the diphthong *ay, the unemphatic plosives were lenited to fricatives (Bauer \& Leander 1927: § 11). This development affected the entire Aramaic speech area, but the exact conditioning may vary per dialect. Syriac, for instance, preserves plosives after ay (Nöldeke 1966: § 23): contrast Syriac baytā 'house' with Biblical Aramaic

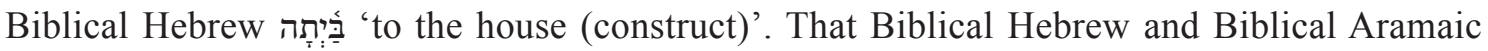
show the same conditioning suggests that this is a shared development in the reading tradition.

\subsection{Gemination of *y after $i$ vowels}

In Biblical Hebrew, the reflex of word-internal $* i y V$ is always $i y y V$, with gemination of the * $y$,

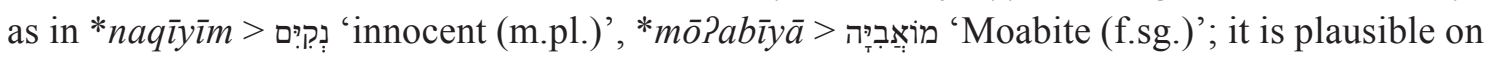
morphological grounds that the gemination is secondary in these forms. ${ }^{8}$ In Biblical Aramaic,

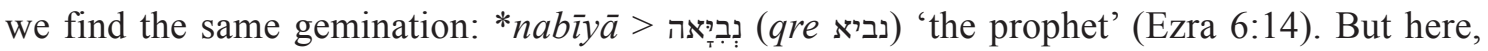

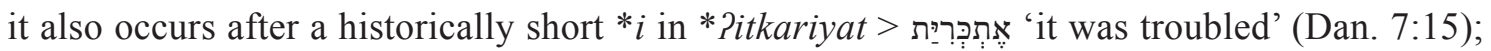
that the vowel preceding $* y$ here was short $* i$ can be seen from strong tG-stem forms like יִתִתיהָב (Dan. 4:13) 'it will be given' and (Ezra 6:9) 'given (m.sg.)', where the interchange between $i$ and $e$ reflects short $* i$ (see $\S 3.1$ below). Thus, it appears that the length of the $i$ vowel was insubstantial: $* \breve{\bar{l} y} V>* \overline{\check{l}} y y V>i y y V$. Not many instances of $* i y V$ with short $* i$ are found in Hebrew, since these so-called triphthongs were contracted at an earlier date (Suchard 2016a; 2016b), but in isolated forms where the *iy $V$ sequence was restored (or borrowed from another dialect), we also find this gemination, as in *hōmiya > המיָּיָ 'noisy (f.sg.)' (Prov. 7:11, 9:13;

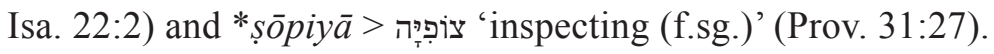

\subsection{Vowel reduction}

The gemination of $* y$ after $i$ vowels ( $§ 2.6$ ) is obviously conditioned by the quality of the preceding vowel. ${ }^{9}$ The short $* i$ vowels found in these Biblical Aramaic and occasional Biblical Hebrew forms stood in unstressed, open syllables. At a certain point, short vowels in this position were reduced to $* a$ (and later frequently deleted) in both languages. Since only $* i$ conditioned gemination of a following $* y$, the gemination must have taken place before the reduction of short $*_{i}$ in open, unstressed syllables to ${ }^{*} ;$; otherwise, the reflexes of all short vowels in this position should have behaved the same and the gemination of * $y$ could not have taken place in the way it did.

If the gemination of $* y$ was a shared development that took place in the reading tradition, as its identical conditioning in Biblical Hebrew and Biblical Aramaic suggests, the subsequent reduction of unstressed short vowels in open syllables must also be. The shared rules for the vocalization of proclitic particles $(\S 2.4)$, too, are most easily understood as having arisen during the process of vowel reduction. Thus, it appears that qualitatively distinct short vowels in open, unstressed syllables were still preserved in the earliest stages of the reading tradition.

\footnotetext{
8 For these examples, we may argue that *naqīy- belongs to the common *qatīl-adjective pattern (*qatill- not being an attested Hebrew adjective pattern), while *mōiabiy- contains the gentilic suffix, which should probably be reconstructed as $*_{-i} \bar{y}$ - in order to more easily connect it with the variant form *-a $y$-reflected, for instance, in Aramaic.

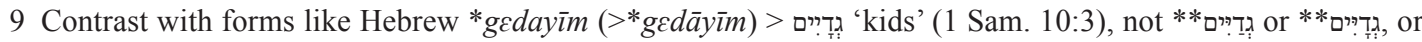

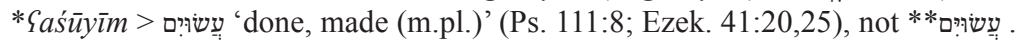


As I hope to argue elsewhere, unstressed $* u(>* o)$ in open, word-initial syllables was normally preserved in both languages, surfacing in vocalization as håțēp qåmeș, as in Hebrew

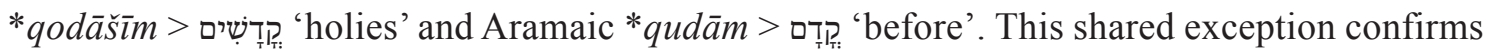
that vowel reduction occurred simultaneously in Biblical Hebrew and Biblical Aramaic.

\subsection{Unstressed *i, *u often $>\varepsilon, \supset$}

In closed syllables, unstressed short vowels were preserved. Proto-Semitic short $* i$ and $* u$ (and the vowels that merged with them) often show up as $i$ and $u$, respectively, in both Biblical Hebrew and Biblical Aramaic, but are also often reflected by $\varepsilon(s \bar{g} o l)$ and $っ$ (qåmes hุåtup $)$, respectively. While $\varepsilon$ usually occurs near gutturals and sometimes near nasals, $\supset$ is the more common reflex of *u, with $u$ mainly occurring before geminates. The distribution is not completely phonetically conditioned, however. In Hebrew, these vowels probably go back to precursors with an intermediate quality, ${ }^{*} e$ and $* o$ (Suchard 2016a; 2017), but as will be argued in the next section, this may not originally be the case for Biblical Aramaic.

\section{DISCREPANCIES BETWEEN BIBLICAL HEBREW AND BIBLICAL ARAMAIC}

\subsection{Reflexes of stressed *i, *u}

In Hebrew, stressed vowels were often lengthened (even far before the phonetic lengthening discussed in $\S 2.1$ ). When historically short $* i$ and $* u$ remained short in stressed syllables, as

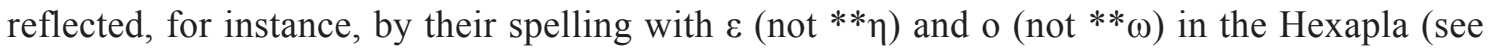
Kantor 2017: 251-273), they virtually always yield Biblical Hebrew $e$ and $o$, as in *kabid $>$ כָָּ 'it was heavy', *qatún > קטָ 'it was small'. In Suchard (2016a; 2017), I argue that this confirms the early shift of Proto-Semitic $* i$ and $* u$ to pre-Hebrew $* e$ and $* o$ reflected by a number of other sound changes. ${ }^{10}$

In Biblical Aramaic, the reflexes of stressed $* i$ and $* u$ as $e$ and $o$ are not infrequent, as in

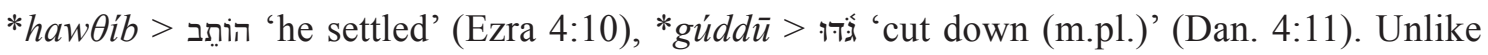
in Hebrew, however, we also find stressed $* i>i$ and stressed $* u>u$, as in $* w a$-battitilu $\bar{u}>$ in

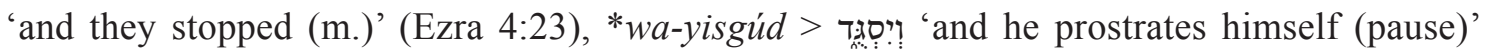

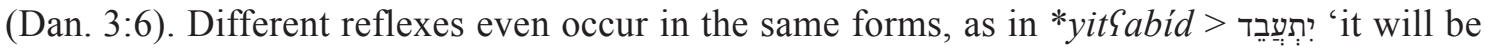
made (m.)' (Ezra 6:11, 7:23, Dan. 3:29) besides 'idem (pause)' (Ezra 6:12, 7:21).

As the last example illustrates, there is some correlation between pausal (i.e. sentence-final) position and the reflex of $* i$ as $i$ (Bauer \& Leander 1927: $§ 5 \mathrm{e}-\mathrm{k}$ ). Unlike the Biblical Hebrew phenomenon of pausal lengthening, however, no rule like ' $* i>i$ in pausa, $>e$ elsewhere' can be formulated; there are too many exceptions. DeCaen (2004) tries to salvage this approach by expanding the definition of pausal forms and introducing the concept of a "pausal phrase". Thus, for instance, it is "phrased together with the word bearing major pause" (DeCaen 2004: 218, emphasis in

10 But see Kantor's (2017) convincing arguments for a qualitative difference between these vowels and long $/ \overline{\mathrm{e}} /$ and $/ \overline{\mathrm{o}} /$ in the Hexaplaric pronunciation. I agree that short /e/ and /o/ probably had more lax pronunciations, whether $[\mathrm{I}]$ and $[\mho]$, as he suggests, or some other values, such as $[\varepsilon],[0]$ (parallel to the reflexes of long and

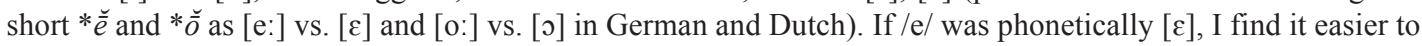

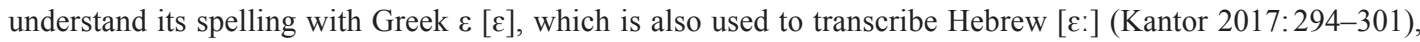
not with $1[i]$. 
original), as indicated by the cantillation signs. But given his later remark that "minor pause [i.e. sentence-internal pauses] may be sufficient to project a pausal phrase" (DeCaen 2004: 222), emphasis in original), I do not understand where we should ever expect $e$, since every word occurs in a prosodic phrase ending in a pause. Even so, this account leaves a fair number of exceptions unexplained, so an alternative explanation would be preferable.

The irregularity in the reflexes of stressed $* i$ and $* u$ suggests that we are not dealing with an outcome of sound change. Rather, some other process may be at work. Two considerations may point us in the right direction. First, we are dealing with sounds (short $* i$ and $* u$ ) that no longer occur in stressed position in Biblical Hebrew (having shifted to $*_{e}$ and $* o$ ). And second, the Biblical Aramaic changes of $* i>e$ and $* u>o$ are limited to closed syllables, the same environment where we see these reflexes in Biblical Hebrew. In open syllables, Biblical Hebrew shifted the stress away from short vowels, which were subsequently reduced, as in *kabid $\bar{u}>$

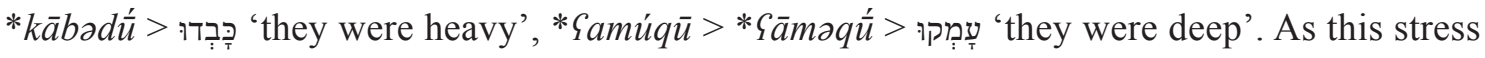
shift did not affect Biblical Aramaic (see $\S 3.4$ below), ${ }^{*} i$ and $* u$ were preserved in this position, and here we always find $i$ and $u$, as in *haddiqu $>$ ה 'they (m.) crushed (pause)' (Dan. 6:25), *šbúqū > שִׁבְקוּ 'leave (m.pl.)' (Ezra 6:7). This suggests that the varying reflexes in Biblical Aramaic result from phonological adaptation to Biblical Hebrew. When the Aramaic texts were incorporated into the Hebrew Bible, readers started applying Hebrew phonology to them; even though Aramaic was more dominant in daily life, the fact that Biblical Aramaic only makes up about 1 percent of the Hebrew Bible would have motivated the adaptation of the Aramaic texts to Hebrew phonology rather than vice versa. Since this Hebrew phonology lacked short $* i$ and $* u$, the closest approximations were used instead: ${ }^{*} e$ and ${ }^{*} o$ in unstressed syllables, ${ }^{*} \bar{l}$ and ${ }^{*} \bar{u}$ in open, stressed syllables, and either reflex in closed, stressed syllables. The greater frequency of $i$-reflexes in pause can be attributed to the phonetic lengthening that affects phrase-final vowels in all languages (Wightman et al. 1992: 1710). This would have made Aramaic $* i$ and $* u$ in this position more similar to Hebrew $* \bar{\imath}$ and $* \bar{u}$.

\subsection{Diphthongs}

The Proto-Northwest-Semitic diphthong *ay, which is more common in our corpus than its counterpart *aw, also shows different behaviour in Biblical Aramaic and Biblical Hebrew. In Hebrew, it was contracted to $*_{\bar{e}}$ in non-final syllables and preserved in final syllables (Suchard 2016a: 140-148). ${ }^{11}$ In Biblical Aramaic, we find a higher proportion of *ay being preserved

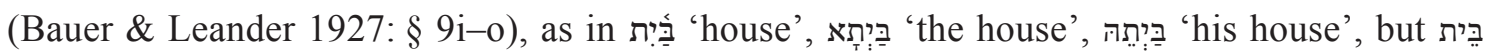

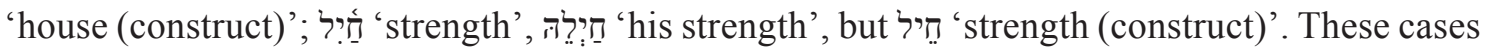
of preserved word-internal *ay contrast with other words where it was contracted, as in 'animal' and, with further assimilation to $\varepsilon$ before the following $a$, עִ עִ עִ 'on us'. In these latter cases, *ay could not have been analogically restored, but this could have taken place in the former examples. Word-internally, contraction thus appears to be the regular development. The main position in which we find * ay preserved where it cannot be analogical is in the final syllable of a phonological word. Thus, it seems like the same rule affected both Hebrew and pre-Biblical Aramaic: word-internal $* a y$ was contracted to $* \bar{e}$, while $* a y$ was retained in final syllables. In Aramaic, however, *ay was more frequently restored by analogies like *kásp 'silver' : *kaspáa

11 Instances of preserved word-internal $a y$, as in לִ לְיָלָ 'night', are analogical to forms where the diphthong occurred in the final syllable at the time of contraction. 
'the silver' = *báyt 'house' : *baytầ 'the house'. ${ }^{12}$ Together with the epigraphic evidence for early contraction of *ay in Hebrew (Zevit 1980), the fact that these secondary diphthongs in Biblical Aramaic were not contracted suggests that the contraction took place separately in the two languages, rather than being a shared sound change in the reading tradition.

The apparent reflexes of $* a y$ as $a$ and $a$ in the pronominal suffixes on plural nouns seem to result from a morphological change, not a sound change. The contraction of $* a y$ to $* \bar{e}$ in

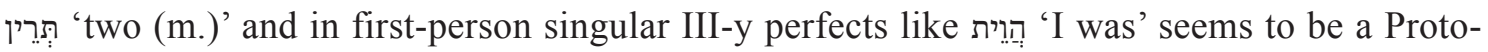
Aramaic development, since it is reflected in all dialects (Bauer \& Leander 1927: § 9n-o).

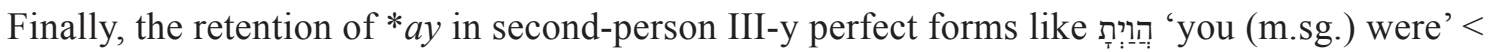
*hawáytā could be analogical to forms with the short version of the second-person masculine perfect ending, *hawáyta $>$ *hawáyt, where the diphthong would have been preserved. ${ }^{13}$

\subsection{Word-final $*_{-} \bar{e}>*_{-} \bar{\varepsilon}$}

In Hebrew, word-final *-e was lowered to *- יבנֶה 'he will build'. This sound

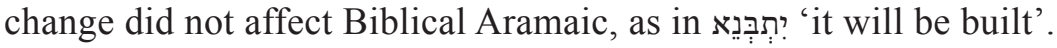

\subsection{Vowel length and position of the stress}

As was most influentially noted by Cantineau (1931), both Hebrew and Aramaic reflect a stress system where the originally penultimate syllable of every phonological word was accented. Both languages subsequently underwent various stress shifts. Those affecting Aramaic are discussed by Birkeland (1940: 1-4); for the more complex history of Hebrew accentuation, see Suchard (2016a: 100-113). One pervasive change that affected Hebrew (but not Aramaic) shifted the stress from short vowels in open syllables to the following syllable: thus, we find

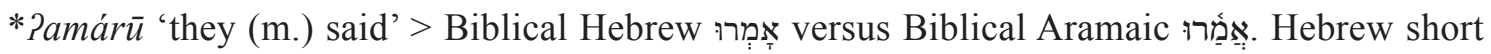
vowels were also lengthened in many environments, conditioned by the stress; Aramaic did not participate in these lengthening changes. ${ }^{14}$

\section{$3.5 * y>$ ?}

In the qre of Biblical Aramaic, etymological $* y$ has mostly shifted to ? between * $\bar{a}$ and a stressed

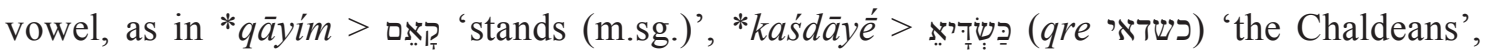

12 This may have been motivated by the prominent role of the emphatic state (i.e. the form of the noun with the suffixed article). In Hebrew, the suffixed forms of the noun are semantically close to the construct state, since both indicate possession. In Aramaic, however, the emphatic state could transparently be formed by attaching the suffix $*_{-} \bar{a}$ to the absolute state, which would facilitate the spread of the preserved diphthong. This would then provide a model for the preserved diphthong to be reintroduced into other suffixed forms of the noun.

13 The different behaviour of Proto-Northwest-Semitic first-person singular *hawaytu > Proto-Aramaic *hawết and second-person masculine singular *hawayta $>*$ hawáyt is due to the longer preservation of word-final $*_{-} a$ than word-final $*-u$ in Proto-Aramaic. This different behaviour can be seen from the preservation of the feminine suffix $-t$ in adverbs, originally accusatives: *rahmata $>r h m t$ ' as a gift' (Hoftijzer \& Jongeling 1995 s.v. $r h m h_{1}$ ), but nominative *rahmatu $>$ *rahmat $>*$ rahma $a$ 'love' with loss of word-final $*-t$ after stressed vowels preceding the loss of *-a. It may also explain the different behaviour of the triphthongs in III-wy roots: *banaya $>*$ bana $\bar{a}$ 'he has built', but *yibnayu $>$ *yibnay $>$ *yibne 'he builds' with loss of * $-u$ before triphthong contraction. However, this may also be due to the different behaviour of triphthongs in *-a versus those in *-u, as in Hebrew (Suchard 2016b). 14 The occasional instances of pausal lengthening in Biblical Aramaic have been explained as Hebraisms, which seems plausible. 


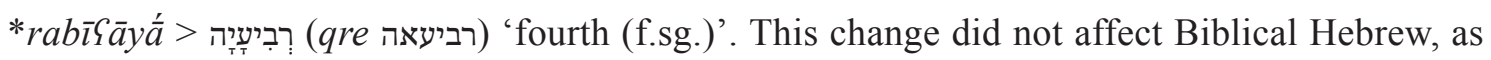

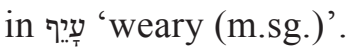

\section{CONCLUSION}

We can clearly distinguish between sound changes that affected both Biblical Hebrew and Biblical Aramaic and ones that are limited to one language. As predicted, the latest sound changes, only just antedating the Masoretic period, are found in both of the Hebrew Bible's languages. In the relative chronology given in Suchard (2016a:276-283), the latest Hebrew sound changes which clearly did not affect Biblical Aramaic are (5(a)i) (the stress shift of $\S 3.4$ ) and (5(c)ii) (major pausal lengthening); all of the following changes occur in both languages, where this is visible. This matches the assessment that "the changes in (5-8) predominantly seem to have affected the reading tradition (first millennium CE)" (Suchard 2016a:276).

By cancelling out the effects of these sound changes on Biblical Aramaic, we can reverse engineer the original forms. Based on comparison with other Aramaic dialects and Semitic languages, this allows us to reconstruct the pronunciation of the Biblical Aramaic texts as they were pronounced at the time the reading tradition was fixed. To give an indication of what that may have sounded like, compare the following reconstruction of Dan. 7:7:

Masoretic Text:

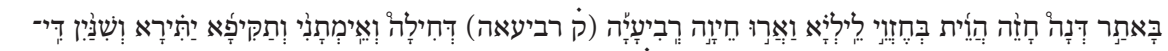

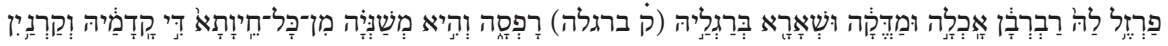

Reconstructed pronunciation:

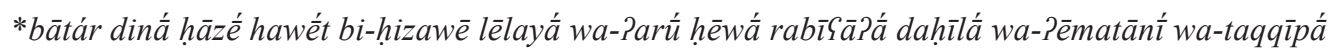

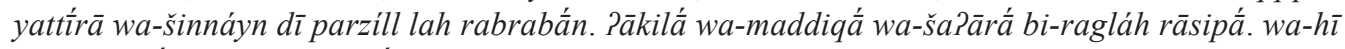
mašannayà min kull ḥêwātá dī qudāmáh wa-qarnáyn Sasár lah.

Translation:

After this, I saw a fourth animal in night visions, frightening and terrifying and exceedingly strong; it had great teeth of iron. It devoured and crushed and it trod the remainder with its feet. It was different from all the animals before it and it had ten horns.

Like many verses in the Biblical Aramaic corpus, the one reconstructed here shows some differences between the received pronunciation, as reflected by the vocalization and qere notes, ${ }^{15}$ and the consonantal text (or ketiv). In Daniel 7:7, this is exemplified by *rabī $\bar{\imath} \bar{a}$ ? $\bar{a}$ 'fourth (f.sg.)', spelled רביעיה (with yod for pronounced ?), and *bi-ragláh 'with its feet', spelled ברגליה (with a yod that does not match anything in the pronunciation); note also *qudāmáh 'before it', similarly spelled קדמיה, where no separate qere is indicated, but the Masora marks the yod as superfluous (marginal note: יתיר י Since none of the changes we have identified as having taken place in the reading tradition account for the presence of a glottal stop in the adjectival suffix of the first word or the contraction of the diphthong in the personal suffix of the second

15 For the most recent discussion of the function and origin of the qere notes, see Fox 2017. Fox convincingly argues that the qere notes were most likely intended for the copyists, alerting them to a likely misspelling of the consonantal text. Pace Fox, who does not believe that these forms reflect an oral tradition, I agree with Morrow's (1992) arguments that they specifically warn against misspellings based on the reading tradition that scribes were familiar with (as the name qre, 'it is read', already suggests). A note like that found with 'fourth (f.sg.)' in Dan. 7:7 should then be interpreted as 'רביעיה: sic, even though it is read as רביעאה'. 
(and third) word, these features must be reconstructed for the pronunciation as it was codified in the reading tradition. Here, as more generally, we find morphological differences between the oldest pronunciation of Biblical Aramaic and the consonantal text. The implications of this consistent mismatch between the Biblical Aramaic reading tradition and the consonantal text remain to be discussed at another time.

\section{REFERENCES}

Allen, W. Sidney 1987. Vox Graeca:The Pronunciation of Classical Greek. 3rd edn. Cambridge: CUP.

Bauer, Hans \& Pontus Leander 1927. Grammatik des Biblisch-Aramäischen. Halle: Max Niemeyer.

Birkeland, Harris 1940. Akzent und Vokalismus im Althebräischen. Oslo: Dybwad.

BRockelmann, Carl 1968. Syrische Grammatik. 11th edn. Leipzig: VEB Verlag Enzyklopädie.

BrønNo, Einar 1943. Studien über hebräische Morphologie und Vokalismus. (Abhandlungen für die Kunde des Morgenlandes 28) Leipzig: Deutsche Morgenländische Gesellschaft.

Cantineau, Jean 1931. De la place de l'accent de mot en hébreu et en araméen biblique. Bulletin d'Études Orientales $1: 81-98$

DeCaen, Vincent 2004. The Pausal Phrase in Tiberian Aramaic and the Reflexes of *i. Journal of Semitic Studies 49(2): 215-224.

EldAR, Ilan 2013. Ashkenazi Pronunciation Tradition: Medieval. In: G. KhAn (ed.), Encyclopedia of Hebrew Language and Linguistics, I: A-F: 185-192. Leiden: Brill.

Fox, Michael V. 2017. The Qeré in the Context of the Masorah Parva. In: F.E. Greenspahn \& G.A. Rendsburg (eds), Le-ma'an Ziony: Essays in Honor of Ziony Zevit: 156-174. Eugene: Cascade.

Glinert, Lewis 2013. Ashkenazi Pronunciation Tradition: Modern. In: G. Khan (ed.), Encyclopedia of Hebrew Language and Linguistics. I: A-F: 192-198. Leiden: Brill.

Gzella, Holger 2011. Imperial Aramaic. In: S. Weninger (ed.), The Semitic Languages: 574-586. Berlin: De Gruyter Mouton.

HoftiJzer, Jacob \& Karel Jongeling 1995. Dictionary of the North-West Semitic Inscriptions. Leiden: Brill.

Janssens, Gerard 1982. Studies in Hebrew Historical Lingusitics Based on Origen's Hexapla. Leuven: Peeters.

Kantor, Benjamin P. 2017. The Second Column (Secunda) of Origen's Hexapla in Light of Greek Pronunciation. $\mathrm{PhD}$ dissertation, The University of Texas at Austin.

Khan, Geoffrey 1996. The Tiberian Pronunciation Tradition of Biblical Hebrew. Zeitschrift für Althebraistik 9: 1-23.

Khan, Geoffrey 2013a. A Short Introduction to the Tiberian Masoretic Bible and its Reading Tradition. Piscataway: Gorgias.

KHan, Geoffrey 2013b. Syllable Structure: Biblical Hebrew. In: G. KHan (ed.), Encyclopedia of Hebrew Language and Linguistics, III: P-Z: 666-676. Leiden: Brill.

KHAN, Geoffrey 2013c. Vowel Length: Biblical Hebrew. In: G. KHAN (ed.), Encyclopedia of Hebrew Language and Linguistics, III: P-Z:981-985. Leiden: Brill.

Lisowsky, Gerhard 1940. Die Transskription der hebräischen Eigennamen des Pentateuch in der Septuaginta. PhD dissertation, University of Basel.

Morag, Shelomo 1964. Biblical Aramaic in Geonic Babylonia: The Various Schools. In: H.B. Rosén (ed.), Studies in Egyptology and Linguistics in Honour of H.J. Polotsky: 117-131. Jerusalem: The Israel Exploration Society.

Morrow, William S. 1992. Kethib and qere. In: D.N. Freedman (ed.), The Anchor Bible Dictionary, IV: K-N: 24-30. NY: Doubleday.

MuraoKA, Takamitsu 1976. Segolate Nouns in Biblical and Other Aramaic Dialects. Journal of the American Oriental Society 96(2): 226-235.

NöLDEKE, Theodor 1966. Kurzgefasste syrische Grammatik. Reprint of the 2nd edn. Darmstadt: Wissenschaftliche Buchgesellschaft.

SÁEnz-Badillos, Angel 1993. A History of the Hebrew Language. Tr. John Elwolde. Cambridge: CUP.

Staples, William E. 1927. The Hebrew of the Septuagint. The American Journal of Semitic Languages and Literatures 44: 6-30. 
Suchard, Benjamin D. 2016a. The Development of the Biblical Hebrew Vowels. PhD dissertation, Leiden University. Suchard, Benjamin D. 2016b. The Hebrew Verbal Paradigm of Hollow Roots: A Triconsonantal Account. Zeitschrift der Deutschen Morgenländischen Gesellschaft 166(2):317-332.

Suchard, Benjamin D. 2017. A Triconsonantal Derivation of the lamed-he Paradigm. Kleine Untersuchungen zur Sprache des Alten Testaments und seiner Umwelt 22:205-221.

Suchard, Benjamin D. 2018. The Vocalic Phonemes of Tiberian Hebrew. Hebrew Studies 59: 193-207.

Suchard, Benjamin D. forthcoming. Sound Change in the Hebrew Reading Tradition. In: L. van BeEk (ed.), Language Change in Epic Greek and Other Oral Traditions. Leiden: Brill.

Wightman, Colin W., Stefanie Shattuck-Hufnagel, Mari Ostendorf, \& Patti J. Price 1992. Segmental Durations in the Vicinity of Prosodic Phrase Boundaries. The Journal of the Acoustical Society of America 91: 1707-1717.

Zevit, Ziony 1980. Matres Lectionis in Ancient Hebrew Epigraphs. Cambridge, MA: American Schools of Oriental Research. 